Strahlenforsch. Bd. 2, 1. (13) Meyer, E., Arch. f. Pвych. Bd. 89, 177, 1929. (14) O. Bunke, O. Foerster, Handbuch d. Neurologie, Bd. 2. (15) Wartenberg, R., Zbl. Neur. Bd. 38, 220, 1924. (16) Wartenberg, R., Zschr. f. Neur. Bd. 94, 585, 1925. (17) 相川, 种經學雜誌。第 34 兊. 第 1 號. 1頁. (18) 茷野，最新㗨學。第 4 吩。第 12 號. 12 頁. (19) 新, 腦と种經. 第3 號. 48 頁. (20) 淺 野，最新㗨祭。第 5 卷. 第 6 號. 21 面. (21) 稻田, 部經學雜誌. 第 37 兊. 第 3 號. 173 頁. (22) 伊藤,

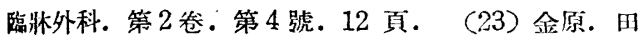
村, 利經學雜誌. 第 40 卷. 557 頁. (24) 旅藤, 日 本レ學誌. 第 5 卷. 157 頁. (25) 碳藤, 日本外科學
會雜誌. 第 30 回. 1 頁. (26) 諏訪, 軍㗨国雜誌. 第 258 號. 1841 页. (27) 關, 日本レ學會誌. 第 4

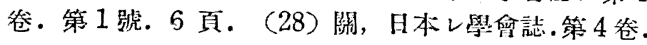
第2 號. 1 页. (29) 日村, 种經學襍誌。第 39 橆。

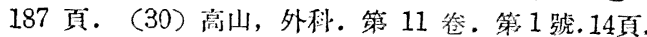
(31) 高山, 外科. 第 11 怣. 第 4 號. 15 頁，(32) 平澤, 腦及种經. 第 1 號. 1 頁. (33) 西川. 福原, 计 中，慆及种經。第 1 號. 46 頁. (34) 柳潈, 京都府 立醫大誌。第 1 兊. 547 頁. (35) 柳澤，日本レ學會

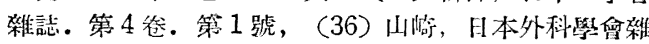
誌. 第 34 回. 53 頁. (37) 山本, 福网㯊學. 第 33 参. 618 頁. (38) 吉阔, 軍醫国雜誌。第 3201 號. 面 (39) 吉阙, 雬㗨国雜誌. 第 322 號. 239 頁.

\title{
遅鈍性精神薄弱者の體質に關する研究
}

On the Constitution (Biological Reaktions) of the

Feeble-minded of Stupid Form

\begin{tabular}{|c|c|}
\hline & 改授指導） \\
\hline 日本醫科大學啒託 & 平 ${ }_{\text {Hirai }}$ 井 \\
\hline
\end{tabular}

（1）緒 言 Scholz 汇「精神薄弱 は智 的衰弱以上のものである。それては全人格の障碍 である」と述べてるるが，精神薄弱のこれるま゙ の研究には，かかる方向うけにもとづいてなさ れたものは甚だ稀で西つた。また，そのやうな 研究に適雇した，具體的な方法手段の考察も殆 ど行はれなかつた。

精神薄弱の全精神領域の障碍㠻, 精神作用の 搭ひ手で西るところの實體としての腦䯠自體に 求めやうとするのは正當である。しかし乍ら， 賽體的なるのの检索を基礎とする研究方法の外 $K$, 全體的, 機能的李身體的, 生物學的反應態 度を對象とする研究方法によつても, 精神薄弱 の何等かの特質な求めることが出來るのではな いかと考へられる。

我々は，その具體的手段として，單飞一つの 生物學的反應のみ江固執することなく, 諸種反 應態度の間於ける共通の傾向の有無学檢查しょ うとして, 延總數 34 例の, 遲鈍性の一般精神 薄弱存用ひて, 自律神經機能, 皮膚炎症反應, 䯠溫調節機能, 覺醒アミンと對する反應, 食餌 性血糖反應に關する實驗觀察を試みた。ここに その結果を報告する。
（2）自律神經機能 16歲一 48 歲の 18 例 （令 9 例，우 9 例）につき，アドレナリン，ピ ロカルピン，アトロピンによる藥物的檢査，及 び理學的憸查としてアシュネル氏試驗を行つ t。

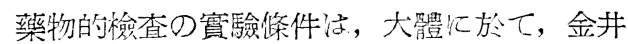
等の方法汇從ひ，アドレナリン及びアトロピン は $1 \%$ 溶液を, ピロカルピンは $1 \%$ 溶液を, 體 重 $10 \mathrm{~kg}$ に對して $0.13 \mathrm{cc} の$ 皮下注射在行つ た。判定の規準としては，アドレナリン 1，血 壓光進（上昇 $30 \mathrm{~mm}$ 以上陽性）2, 脈博增加 （20-30至以上増加陽性）3, 心悸六進, 顔面 蒼白, 四肢震顫, 反射方進, 呼吸頻數, 呼吸性 不整脈。ピロカルピン 1 , 流涎 (注射後 60 分

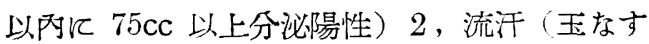
汗の程度) 3、脈博增加（20-30 至以上陽性） 顏面紅潮, 流滬, 鼻汗, 尿意頻數, 心悸六進, 惡心嘔吐, 頭痛。アトロピン 1 , 脈博增加 (20 -30 至以上陽性) 2 , 口內乾燥 3 , 頭痛, 心悸 圥進, 散瞳, 顏面紅潮学檢查し, 以上の各々の $1 ， 2 ， 3$ の, 一症候するもの如十, 二症候 を廿, 三症候存井と判定した。

アシュネル氏試驗恃, 兩側眼球の指頭壓迫 2 
分間に上り，各分つ最後の 20 秒間飞於ける脈 博數应 1 分間の值飞換算し， 2 分間の胍博數の 平均学算出乙一壓迫前值との差を求めた。判定 は增減 5 以下一，6-9+, 10 以上十とした。

以上の實驗の結果を表示すると第 1 表の通り で西る。

郎ち，アドレナリン試驗では，18 例中 14 例 がー, 上例が十, ピロカルピン試驗は, -9 例 +8 例, \#1例, アトロピン試驗は, -14 例, + 3 例, \#1例で亩つた。また全症例の中 3 種 の試驗が全部一のもの8例, 1 つが+のもの 5

第 1 表
例, 2 つが+のもの 2 例, 3 つが+のもの 2 例

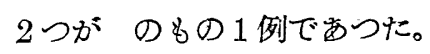

アシュネル試驗は, -9 例, \pm 6 例, (この 中ー 6 のもの 5 例, -7.5 の 例であつテ。

以上の如く, 被驗者济於ては, 各自律神經毒 飞對する反應仙微弱な個體が多く、アシュネル 氏試驗飞於ても, 脈博の增減值が正常者の值 )

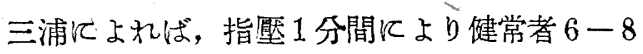
減少，10-15減少陽性）に比較して小さいもの が多かつた。

\begin{tabular}{|c|c|c|c|c|c|c|c|c|c|c|c|c|c|c|c|c|c|c|c|c|}
\hline 症 & & 例 & 1 & 2 & 3 & 4 & 5 & 6 & 7 & 8 & 9 & 10 & 11 & 12 & 13 & 14 & 15 & 16 & 17 & 18 \\
\hline 性 & & 別 & 우 & ㅇ & 우 & के & 우 & f & $\hat{\sigma}$ & $\hat{\delta}$ & 우 & $\hat{0}$ & $\hat{o}$ & $\widehat{\delta}$ & $\delta$ & $\hat{\delta}$ & $\hat{\sigma}$ & q & ㅇ & $\hat{\delta}$ \\
\hline 年 & & 齡令 & 48 & 42 & 30 & 21 & 20 & 33 & 18 & 20 & 41 & 26 & 16 & 27 & 34 & 26 & 19 & 23 & 32 & 38 \\
\hline 智 & 能 & 度 & 痴思 & 倁䍐 & 知照 & 僧鈍 & 痴忽 & 痴忽 & 白痴 & 痴愚 & 疾感 & 愈鈍 & 痴愚 & 痴䍐 & 痴思 & 恸愚 & 知思 & 智銥 & 䂏䍐 & 痴思 \\
\hline \multicolumn{3}{|c|}{ アドレナリン試驗 } & - & - & - & - & + & - & - & + & - & - & + & - & - & + & 一 & - . & - & - \\
\hline \multicolumn{3}{|c|}{ ピロカルピン試驗 } & - & - & - & H & + & + & - & + & - & + & + & - & - & - & - & + & + & + \\
\hline \multicolumn{3}{|c|}{ アトロピン試驗 } & - & - & - & H & - & - & - & + & - & + & + & - & - & - & - & - & - & - \\
\hline \multicolumn{3}{|c|}{ アシニネル試驗 } & $\left(\begin{array}{c} \pm \\
(-\end{array}\right.$ & $\begin{array}{l}- \\
(- \\
4.5)\end{array}$ & $\left(\begin{array}{c}- \\
4.5)\end{array}\right.$ & $\left(\begin{array}{l}- \\
(0)\end{array}\right.$ & $\begin{array}{c}- \\
(+ \\
4.5\end{array}$ & $\begin{array}{c} \pm \\
(- \\
6)\end{array}$ & $\mid \begin{array}{c} \pm \\
(-6)\end{array}$ & $\left|\begin{array}{c}+ \\
(- \\
10.5)\end{array}\right|$ & $\mid \begin{array}{c} \pm \\
(- \\
6)\end{array}$ & $\mid \begin{array}{l} \pm \\
(- \\
75\end{array}$ & $\begin{array}{l}- \\
(- \\
4.5)\end{array}$ & $\frac{-}{(-}$ & $\left|\begin{array}{c}- \\
(- \\
4.5)\end{array}\right|$ & $\mid \begin{array}{c} \pm \\
(- \\
6)\end{array}$ & $\begin{array}{l}-1 \\
(-1 \\
4.5)\end{array}$ & $\begin{array}{l}+ \\
(+ \\
14)\end{array}$ & $\begin{array}{c}+ \\
(- \\
15)\end{array}$ & $\left(\begin{array}{c}- \\
(+ \\
3)\end{array}\right.$ \\
\hline
\end{tabular}

（3）波膚炎症反應皮还の外來刺㦸飞對 する反應態緊憸查の 1 つとして，26 例の被驗 者（今 11 例，우 15 例）如用ひ，カンタリデ

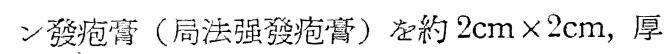
さ約 $2 \mathrm{~mm}$ の圓形溆布したセロファン紙を, アルコホル淸拭を行つた左側前博內側遠位部に 貼布固定して最初汇墢疮が現れる迄時間在測 定した。

全例飞於ける發疮時間は以下の通りで西る。

9 時間 2 例, 10-14 時間 6例, 15-19 時間 1 例, $20-24$ 時間 6 例, $25-29$ 時間 4 例, 30 -34 時間 1 例, 35-39時間 3 例, 40-49 時間 $0,50-54$ 時間 1 例, 120 洔間で敃疱なし 2 例 であつた。郎ち, 發疮時間は 9 時間から52時間 に及び, 更に 120 時間で發疱の見られない個 體が 2 例西つた。

一般健常者に於ける發泡時間は、三浦によれ
第 2 表

\begin{tabular}{|c|c|c|c|c|c|c|}
\hline 例 & 作 & $\begin{array}{l}\text { 性 } \\
\text { 別 }\end{array}$ & $\begin{array}{l}\text { 智能 } \\
\text { 程 度 }\end{array}$ & $\begin{array}{c}\text { 夏季體溫 } \\
\text { (平均) }\end{array}$ & $\begin{array}{l}\text { 冬期體㴧 } \\
\text { (平均) }\end{array}$ & 。 \\
\hline 1 & 18 & $\delta$ & 重症白痴 & 36.49 & 36.21 & +0.28 \\
\hline 2 & 20 & $\delta$ & 痴 悶 & 36.37 & 36.10 & +0.27 \\
\hline 3 & 26 & $\hat{o}$ & 留，埕 & 36.52 & 36.44 & +0.08 \\
\hline 4 & 16 & $\delta$ & 痴 照 & 36.49 & 36.20 & +0.29 \\
\hline 5 & 38 & $\delta$ & 短 學 & 36.53 & 36.23 & +0.20 \\
\hline 6 & 48 & 우 & 痴 墨 & 36.52 & 36.27 & +0.25 \\
\hline 7 & 42 & 우 & 痴 隐 & 36.53 & 36.12 & +0.41 \\
\hline 8 & 30 & q & 知 隐 & 36.44 & 36.39 & +0.05 \\
\hline 9 & 20 & 우 & 倁 罡 & 36.32 & 36.36 & -0.04 \\
\hline 10 & 33 & 우 & 嗾 思 & 36.41 & 36.01 & +0.40 \\
\hline 11 & 41 & के & 疑 愚 & 36.55 & 35.06 & +0.49 \\
\hline 12 & 23 & 우 & 碷 鈍 & 36.51 & 36.14 & +0.37 \\
\hline 13 & 40 & 우 & 輕拝白知 & 36.45 & 36.36 & +0.09 \\
\hline 14 & 32 & 우 & 状知 息 & 36.47 & 36.21 & +0.26 \\
\hline $\begin{array}{l}\text { 總 } \\
\text { 平 } \\
\text { 均 }\end{array}$ & 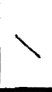 & $\searrow$ & & 36.47 & 36.22 & +0.25 \\
\hline
\end{tabular}



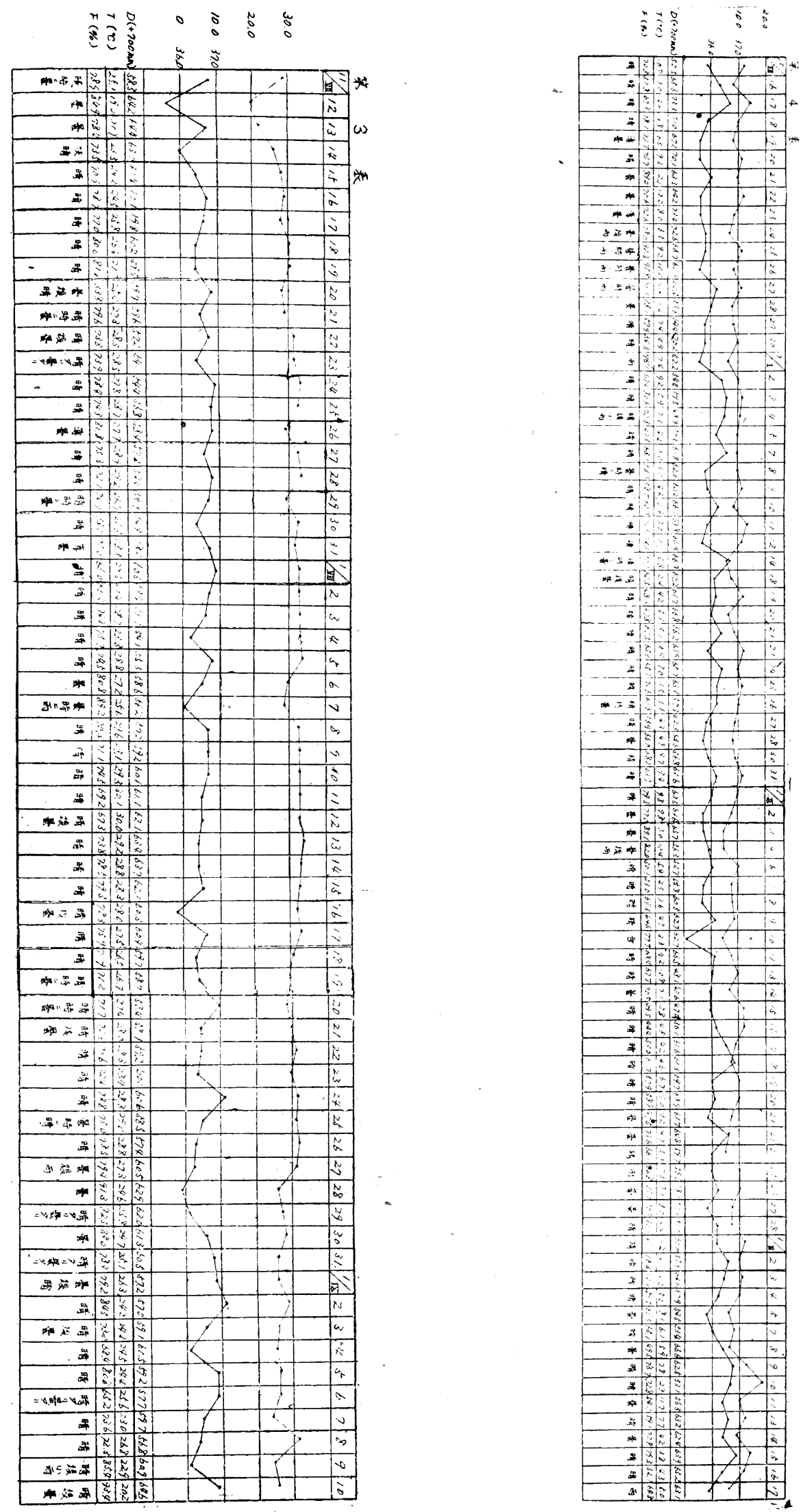
ば, その分价は 6.5 時間一36 時間で, この中 $84.0 \%$ は 8-20 時間で發疮し, 平均壮 13.5 時 間で㐫つた。

前述の被驗者の成績とこの成績を比較すると 被驗者几於ては, 發疮時間 37 時間以上のもの 4 例，20時間以內に發疮の見られたもの10例 (38.4\%。)，120時間で發疱の見られなかつた2 例症除く 24 例の發疱時間の平均汒 23 時間で 西り, 健常者の平均 13.5 時間內以潑疮した ものは26 例中 5 例で西つた。

以上の如く, 被驗者の發揓時間仙健常者の發 疮時間より遲延寸る傾向が認められ, 被驗者の カンタリデンによる湙出性炎症刺钱に對する反 應は，健常者に比較して鈍い個體が多いことが 考へられる。

（4）體溫調節機能 人間の體溫は種々の 條件江應じて恒溫を保持する如く調節されるが この恒溫性必年令的，個體的佂可なり幅の西る ことが, 主とし小兒の體溫の研究に上つて知ら れてるる。㻐達の制止狀態で西る精神薄弱を, 小兒と類比的江考察すること出來ないが, 我 我は小兒體溫飞關する諸研究に示唆を受け, 被 驗者に於ける，體溫調節機能の實驗觀察を行つ た。

被驗者江は16歲一 48 歲の 14 例（今5例 우 9 例）を在ひ, 腋坴體溫沉ついて, 季節的變動 (昭和 22 年 7 月 11 日一 9 月 14 日, 昭和 23 年 12 月 15 日一昭和 24 年 3 月 14 日), 1 日
間の變動,チフス混合ワクチン静脈內注射によ る變動, 溫浴による變動を觀察した。

體溫の季節的變動に關する成績は第 2 表の通 りである。第 2 表は前記體溫測定期間中の最暑 期（昭和 22 年 7 月 20 日- 8 月 19 日）及び 最寒期（昭和 24 年 2 月 1 日- 2 月 28 日） 飞 於ける各症例の午後 $2-3$ 時の體溫測定の成績 である。即ち, 該表によれば, 最暑期體溫と最 寒期體溫の本均の差は $-0.04^{\circ} \mathrm{C}$ から $+0.49^{\circ} \mathrm{C}$ の間に西り, $+0 . \varepsilon 0^{\circ} \mathrm{C}$ 以上のものが $\dot{14}$ 例中 10 例, 14 例平均付 $+0.25^{\circ} \mathrm{C},-0.04^{\circ} \mathrm{C}$ の 1 例在除く 13 例の平均は $0.27^{\circ} \mathrm{C}$ で西つた。こ の成績は健常者に於ける腋荡體溫の季節的變動 の成績 (廣津, 長谷川等) より，一般得大であ ることが明らかである。

次第 2 表儿於て全例中最大の差を示した症 例 11 の夏季及び冬期の體溫表, 及び最暑期, 最寒期に於ける體溫と室溫を同一の圖表復す と第 3 表，第 4 表，第 5 表の通りで西る。

第 3 表，第 4 表浪於けるD $(+700 \mathrm{~mm})$ は 東京地方の平均氣壓， $\mathrm{T}\left({ }^{\circ} \mathrm{C}\right)$ は平均氣溫， $\mathrm{F}$ （\%）下は平均濕度（何れも中央氣象臺による） である。第 3 ，第 4 ，第 5 表によれば，體溫が 室溫飞密接に並行して變動することが㙷著に表 はれてるるが, 他の症例於ても類似の圖表が '得られた。この事實は第 2 表による結果灰實證 してるる。

體溫の1日間の變動は (0 時， 3 時， 6 時,

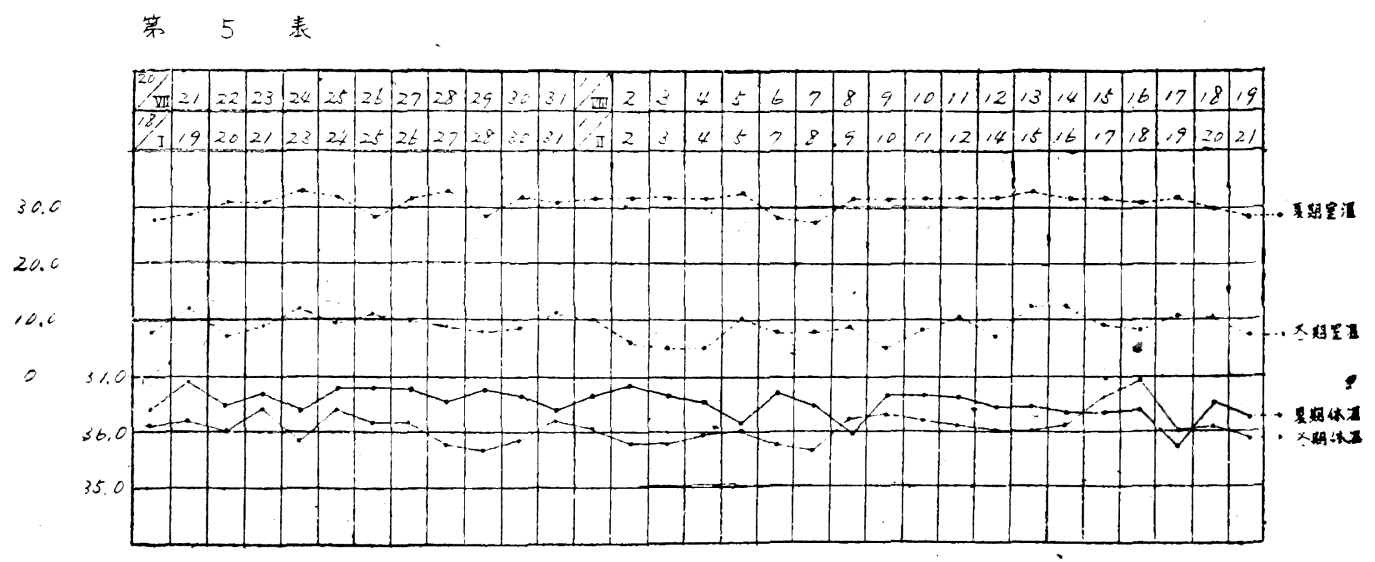


9 時, 12 時, 15 時, 18 時, 21 時測定） $0.3^{\circ} \mathrm{C}$ から $1.4^{\circ} \mathrm{C}$ の間にあり，平均 $0.99^{\circ} \mathrm{C}$ で，健 常者の成績飞比し著明な差違は認められなかつ t。
腸チフス, パラチフス, 混合ワクチン $0.3 \mathrm{cc}$ を靜眽內に注射し，30 分間隔で檢溫した成績 は, 被驗者 14 例飞於ては, 注射時より最高體 溫汇達する迄の時間は 2.5-6.5 時間，平均 4.6

第 6 表

\begin{tabular}{|c|c|c|c|c|c|c|c|c|c|c|c|c|c|c|c|c|c|c|c|}
\hline \multirow[b]{2}{*}{$\begin{array}{c}\text { 症 } \\
\\
\text { 例 }\end{array}$} & \multirow[b]{2}{*}{$\begin{array}{l}\text { 性 } \\
\text { 別 }\end{array}$} & \multirow[b]{2}{*}{$\begin{array}{l}\text { 年 } \\
\text { 齡 }\end{array}$} & \multirow[b]{2}{*}{$\begin{array}{l}\text { 智 } \\
\text { 能 } \\
\text { 程 } \\
\text { 度 }\end{array}$} & \multirow[b]{2}{*}{ 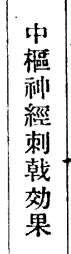 } & \multicolumn{2}{|r|}{ 血 } & \multicolumn{4}{|c|}{ 盟 (最高) } & & & & 筑 & 震 & & 混 & 口 & \multirow[b]{2}{*}{ 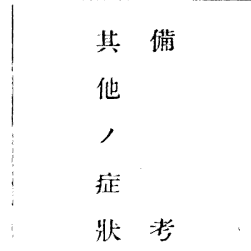 } \\
\hline & & & & & $\begin{array}{l}\text { 注 } \\
\text { 射 } \\
\text { 前 }\end{array}$ & $\begin{array}{l}10 \\
\text { 分 } \\
\text { 後 } \\
\text { 势 } \\
\text { 加 } \\
\text { 数 }\end{array}$ & $\begin{array}{l}\text { 最 } \\
\text { 大 } \\
\text { 值 }\end{array}$ & $\begin{array}{c}\text { 最 } \\
\text { 大 } \\
\text { 塯 } \\
\text { 加 } \\
\text { 数 }\end{array}$ & 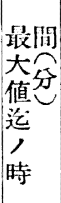 & $\begin{array}{l}120 \\
\text { 分 } \\
\text { 後 } \\
\text { 堵 } \\
\text { 湆 } \\
\text { 教 }\end{array}$ & $\begin{array}{l}\text { 指 } \\
\text { 加 }\end{array}$ & $\begin{array}{l}\text { 吸 } \\
\text { 聕 } \\
\text { 加 }\end{array}$ & $\begin{array}{l}\text { 偲 } \\
\text { 上 } \\
\text { 早 }\end{array}$ & 汗 & 频 & $\begin{array}{l}\text { 六 } \\
\text { 進 }\end{array}$ & 感 & 渴 & \\
\hline 1 & ㅇ & 26 & $\begin{array}{l}\text { 辇知 } \\
\text { 腎 }\end{array}$ & $\begin{array}{l}\text { 淺 } \\
\text { 岞 }\end{array}$ & 97 & $\begin{array}{c}18 \\
(+)\end{array}$ & 115 & $\left|\begin{array}{c}18 \\
(+)\end{array}\right|$ & 10 & $\left(\begin{array}{c}0 \\
(-)\end{array}\right)$ & 4 & 7 & 0.65 & $H$ & - & + & + & - & 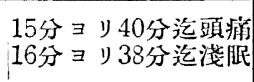 \\
\hline 2 & 우 & 22 & 䂏 & $\mid$\begin{tabular}{|} 
稍移 \\
々動
\end{tabular} & 110 & $\begin{array}{c}25 \\
(H)\end{array}$ & 135 & $\begin{array}{c}25 \\
(H)\end{array}$ & 10 & $\left|\begin{array}{c}10 \\
(+)\end{array}\right|$ & 8 & 3 & 0.60 & - & - & - & - & \pm & \\
\hline 3 & 우 & 33 & $\begin{array}{l}\text { 族 } \\
\text { 忽 }\end{array}$ & 不 & 112 & $\left(\begin{array}{c}0 \\
(-)\end{array}\right)$ & 115 & $(\stackrel{3}{-})$ & 20 & $\left(\begin{array}{c}0 \\
-)\end{array}\right)$ & 14 & 2 & 1.20 & - & - & - & - & - & \\
\hline 4 & \% & 51 & $\begin{array}{l}\text { 知 } \\
\text { 愚 }\end{array}$ & $\left|\begin{array}{|}\mid \text { 殆不 } \\
\text { ド継 }\end{array}\right|$ & 103 & $\begin{array}{c}12 \\
(+)\end{array}$ & 115 & $\left|\begin{array}{c}12 \\
(+)\end{array}\right|$ & 10 & $\left(\begin{array}{c}7 \\
( \pm)\end{array}\right.$ & 6 & 2 & 1.00 & + & \pm & + & - & - & $\begin{array}{l}100 \text { 分 } \text { リ110分迄裂 } \\
\text { 汗 } \text { 件フ淺服。 }\end{array}$ \\
\hline 5 & 우 & 25 & 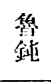 & $\begin{array}{l}\text { 不 } \\
\text { 戀 }\end{array}$ & 95 & $\left(\begin{array}{c}5 \\
( \pm)\end{array}\right.$ & 110 & $\begin{array}{c}15 \\
(+)\end{array}$ & 30 & $\left(\begin{array}{c}5 \\
(+)\end{array}\right.$ & $2 ?$ & 7 & 1.45 & H & - & $\overline{1}$ & + & $H$ & 90 分冷水 $200 \mathrm{cc}$ 㩑取 \\
\hline 6 & 우 & 38 & $\begin{array}{l}\text { 白 } \\
\text { 族 }\end{array}$ & 甭 & 92 & $\left|\begin{array}{c}9 \\
( \pm)\end{array}\right|$ & 101 & $\left|\begin{array}{c}9 \\
( \pm)\end{array}\right|$ & 10 & $(\stackrel{0}{-})$ & 12 & 3 & 0.40 & - & - & - & - & & \\
\hline 7 & 우 & 36 & 熹 & $\begin{array}{l}\text { 不 } \\
\text { 戀 }\end{array}$ & $10 \overline{3}$ & $\left|\begin{array}{c}10 \\
(+)\end{array}\right|$ & 120 & $\left|\begin{array}{c}15 \\
(+)\end{array}\right|$ & 20 & $\begin{array}{c}15 \\
(+)\end{array}$ & 28 & 6 & 0.35 & \pm & - & + & + & - & \\
\hline 3 & 우 & 23 & 䇶 & $\begin{array}{l}\text { 嗜 } \\
\text { 服 }\end{array}$ & 96 & $\left(\begin{array}{c}7 \\
\pm\end{array}\right)$ & 110 & $\left(\begin{array}{c}14 \\
(+)\end{array}\right.$ & 30 & $\left(\begin{array}{c}0 \\
-\end{array}\right)$ & 26 & 2 & 1.10 & - & - & - & - & - & 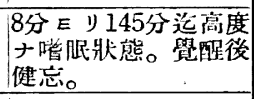 \\
\hline 9 & 우 & 33 & $\begin{array}{l}\text { 瘪 } \\
\text { 愚 }\end{array}$ & $\begin{array}{l}\text { 不 } \\
\text { 變 }\end{array}$ & 103 & $\left|\begin{array}{c}12 \\
( \pm)\end{array}\right|$ & 123 & $\mid \begin{array}{c}20 \\
(H)\end{array}$ & 30 & $\left|\begin{array}{c}12 \\
(+)\end{array}\right|$ & 18 & 2 & 0.70 & + & - & + & + & - & \\
\hline 10 & ㅇ & 40 & $\begin{array}{l}\text { 窽 } \\
\text { 思 }\end{array}$ & $\begin{array}{l}\text { 跓 } \\
\text { 腿 }\end{array}$ & 105 & $\begin{array}{c}15 \\
(+)\end{array}$ & 120 & $\begin{array}{c}15 \\
(+)\end{array}$ & 10 & $(\stackrel{0}{-})$ & 13 & 9 & 0.55 & H & - & - & - & - & 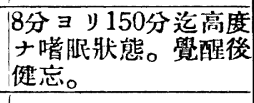 \\
\hline 11 & $\delta$ & 41 & 智 & 不 & 105 & $\left|\begin{array}{c}5 \\
( \pm)\end{array}\right|$ & 130 & (H) & 40 & $\begin{array}{c}17 \\
(+)\end{array}$ & 6 & -3 & $\begin{array}{lll}0 & 35\end{array}$ & - & - & - & - & H & $\because 0$ 分冷水 $150 \mathrm{c}$ 排取。 \\
\hline 12 & 운 & 18 & 矤 & $\begin{array}{l}\text { 不 } \\
\text { 綎 }\end{array}$ & 95 & $(\stackrel{2}{-})$ & 97 & $\left|\begin{array}{c}2 \\
(-)\end{array}\right|$ & 10 & $\left(\frac{0}{-)}\right)$ & 4 & 6 & 0.30 & - & - & - & - & - & \\
\hline 13 & $\delta$ & 29 & 鳘 & $\left|\begin{array}{|c|}\mid \text { 殆不 } \\
\text { |゙戀 }\end{array}\right|$ & 105 & $\left|\begin{array}{c}10 \\
(+)\end{array}\right|$ & 112 & $\left|\begin{array}{c}16 \\
(+)\end{array}\right|$ & 60 & $\left|\begin{array}{c}15 \\
(+)\end{array}\right|$ & 7 & 7 & 0.05 & - & - & - & - & - & \\
\hline 14 & $\delta$ & 15 & 智 & 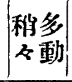 & 105 & $\left(\begin{array}{c}7 \\
\pm\end{array}\right)$ & 121 & $\left|\begin{array}{c}7 \\
( \pm)\end{array}\right|$ & 10 & $\left(\begin{array}{c}0 \\
(-)\end{array}\right.$ & 15 & 5 & 110 & - & - & - & - & - & \\
\hline 15 & 우 & 22 & $\begin{array}{l}\text { 䓡 } \\
\text { 思 }\end{array}$ & |多多| & 100 & $\left|\begin{array}{c}40 \\
(\mathrm{~m})\end{array}\right|$ & 140 & $\left|\begin{array}{c}40 \\
(\mathrm{~m})\end{array}\right|$ & 10 & $\left(\begin{array}{c}10 \\
(+)\end{array}\right.$ & 15 & 7 & 0.80 & \pm & - & - & - & - & $\begin{array}{l}10 \text { 分 } \exists \text { y } 20 \text { 分迄多辩 } \\
\text { 多耐, 激泣。 }\end{array}$ \\
\hline 16 & \& & 30 & $\begin{array}{l}\text { 筥 } \\
\text { 息 }\end{array}$ & 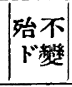 & 93 & $\begin{array}{c}62 \\
(\mathrm{~m}) \\
\end{array}$ & 155 & $\left(\begin{array}{c}62 \\
(\mathrm{H}) \\
\end{array}\right.$ & 10 & (H) & -8 & 9 & 0.55 & - & - & H & $H$ & + & $\begin{array}{l}6 \text { 分心悸，10分頭痛 } \\
\text { 习訴フ。 }\end{array}$ \\
\hline 平 & & & & & & 14.9 & & 18. & & 7.3 & .9 & 4.7 & 0.69 & & & & & & \\
\hline
\end{tabular}


$-30-(602)$

時間, 最高體溫岋 $38.0^{\circ} \mathrm{C}-39.9^{\circ} \mathrm{C}$, 平均 39.02 ${ }^{\circ} \mathrm{C}$, 弡熱時間は 10.0 - 30.0 時間, 平均 15.6. 時間であつた。同じ試驗を男女健常者 10 . 例飞 行つた成績は, 最高觶溫儿達する迄の時間の平 均は 2.0 時間, 最高體溫の平均仙 $39.5^{\circ} \mathrm{C}$, 發 熱時間の平均は 9.5 時間であつた。この成績 によれば, 被驗者は健常者に比し最高體溫飞達
する迄の時間が延長し, 發熱時間が長く, 乐溫 に戻る迄に長時間を要するといふ結果存示し た。

最後に, 被驗者及び健常對照例 20 例を用ひ $42^{\circ} \mathrm{C}$ 前後の溫浴を 10 分間行はせて, 浴直前 浴直後, 其後 30 分間隔で體溫在測定し, 浴前 體溫に戻る迄の時間を測定したが，兩者に顯著

第 7 表

\begin{tabular}{|c|c|c|c|c|c|c|c|c|c|c|c|c|c|c|c|c|c|c|}
\hline \multirow[b]{2}{*}{$\begin{array}{c}\text { 症 } \\
\text { ' } \\
\text { 例 }\end{array}$} & \multirow[b]{2}{*}{$\begin{array}{l}\text { 性 } \\
\text { 別 }\end{array}$} & \multirow[b]{2}{*}{$\begin{array}{l}\text { 年 } \\
\text { 齡 }\end{array}$} & \multirow[b]{2}{*}{$\begin{array}{l}\text { 巾 } \\
\text { 柶 } \\
\text { 种 } \\
\text { 經 } \\
\text { 刺 } \\
\text { 戟 } \\
\text { 効 } \\
\text { 果 }\end{array}$} & \multicolumn{2}{|r|}{ 血 } & \multicolumn{4}{|c|}{ 迦 (最高) } & \multirow[b]{2}{*}{$\begin{array}{l}\text { 脈 } \\
\text { 搏 } \\
\text { 堵 }\end{array}$} & 呼 & & 登 & 霞 & & 溫 & 口 & \multirow[b]{2}{*}{$\begin{array}{c}\text { 其 備 } \\
\text { - 他 } \\
\text { ～} \\
\text { 症 } \\
\text { 狀 考 }\end{array}$} \\
\hline & & & & $\begin{array}{l}\text { 注 } \\
\text { 射 } \\
\text { 前 }\end{array}$ & $\begin{array}{l}10 \\
\text { 分 } \\
\text { 後 } \\
\text { 塤 } \\
\text { 加 } \\
\text { 数 }\end{array}$ & $\begin{array}{l}\text { 最 } \\
\text { 大 } \\
\text { 值 }\end{array}$ & $\begin{array}{c}\text { 最 } \\
\text { 大 } \\
\text { 塯 } \\
\text { 加 } \\
\text { 数 }\end{array}$ & 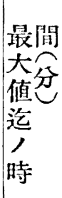 & $\begin{array}{c}120 \\
\text { 分 } \\
\text { 後 } \\
\text { 坫 } \\
\text { 加 } \\
\text { 数 }\end{array}$ & & $\begin{array}{l}\text { 吸 } \\
\text { 坮 } \\
\text { 加 }\end{array}$ & $\begin{array}{c}\text { 溫 } \\
\text { 上 } \\
\text { 昇 }\end{array}$ & 汗 & 䫍 & $\begin{array}{l}\text { 悸 } \\
\text { 䒕 }\end{array}$ & 感 & 渴 & \\
\hline 1 & 우 & 36 & \begin{tabular}{|l} 
胸不 \\
快 \\
部感
\end{tabular} & 103 & (H) & 125 & (H) & 10 & $(\stackrel{4}{\rightarrow})$ & 8 & 5 & 0.75 & - & - & - & + & + & 10分四肢溫感。頭痛 \\
\hline 2 & $\hat{o}$ & 29 & \begin{tabular}{|} 
稍多 \\
々 辩 \\
\end{tabular} & 105 & 20 & 125 & $\left(\begin{array}{c}20 \\
(H)\end{array}\right.$ & 10 & $(\stackrel{0}{-})$ & 8 & 13 & 0.50 & \pm & + & H & - & \pm & 頭重感。腄服陻碍。 \\
\hline 3 & 우 & 20 & \begin{tabular}{|l|} 
焱 \\
快 \\
感 \\
\end{tabular} & 102 & (H) & 127 & $\begin{array}{c}25 \\
(H)\end{array}$ & 10 & $\left(\begin{array}{c}3 \\
-\end{array}\right)$ & 10 & 9 & 0.70 & - & - & \pm & $H$ & + & 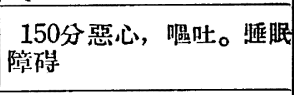 \\
\hline 4 & ㅇ & 24 & $\begin{array}{l}\text { 不 } \\
\text { 快 } \\
\text { 感 }\end{array}$ & 135 & $\begin{array}{c}10 \\
(+)\end{array}$ & 145 & $\left|\begin{array}{c}10 \\
(+2\end{array}\right|$ & 10 & $\left(\begin{array}{c}0 \\
(-)\end{array}\right.$ & 16 & 4 & 0.45 & - & \pm & + & - & $H$ & 頭痛。 \\
\hline 5 & q & 36 & 不 & 90 & $\begin{array}{c}15 \\
(+)\end{array}$ & 120 & $\begin{array}{c}30 \\
(\mathrm{H})\end{array}$ & 20 & $\begin{array}{c}5 \\
( \pm)\end{array}$ & 6 & 5 & 0.35 & \pm & - & - & - & - & \\
\hline 6 & $\delta$ & 19 & $\begin{array}{l}\text { 秋 } \\
\text { 快 } \\
\text { 悠 }\end{array}$ & 113 & $\mid \begin{array}{c}7 \\
( \pm)\end{array}$ & 123 & $\mid \begin{array}{c}10 \\
(+)\end{array}$ & 20 & $\left|\begin{array}{c}7 \\
( \pm)\end{array}\right|$ & -4 & -1 & 0.50 & - & - & - & - & \pm & $\begin{array}{l}\text { 40分四肢冷感。60分排永 } \\
\text { 唯吧障碍。 }\end{array}$ \\
\hline 7 & o & 17 & $\begin{array}{l}\text { 不 } \\
\text { 快 } \\
\text { 感 }\end{array}$ & 112 & $\begin{array}{c}13 \\
(+)\end{array}$ & 145 & $\begin{array}{c}33 \\
(\mathrm{H})\end{array}$ & 50 & $(\stackrel{1}{-})$ & 22 & 10 & 0.50 & - & - & 曲 & - & HI & $\begin{array}{l}\text { 25分全身冷感。 } 40 \text { 分尿意 } \\
\text { 50分排尿。180 分惡心。 } \\
\text { 唓眠障碍。 }\end{array}$ \\
\hline 8 & 우 & 29 & 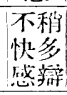 & 110 & $\begin{array}{c}13 \\
(+)\end{array}$ & 128 & $\begin{array}{c}18 \\
(+)\end{array}$ & 20 & $(\stackrel{2}{-})$ & $4^{\circ}$ & 11 & 0.20 & - & - & H & \pm & + & $\begin{array}{l}\text { 25分胸部不快感。頍痛。 } \\
\text { 16分惡心。23分尿意。棰 } \\
\text { 报障碍 }\end{array}$ \\
\hline 9 & $\hat{3}$ & 30 & \begin{tabular}{|l|} 
㹻 \\
快 \\
感
\end{tabular} & 118 & $\begin{array}{c}22 \\
(H)\end{array}$ & 140 & $\mid \begin{array}{c}22 \\
(t+)\end{array}$ & 10 & $\left(\begin{array}{c}0 \\
(-)\end{array}\right)$ & 1 & 9 & 0.45 & \pm & - & H & \pm & 曲 & 唾眠障碍。 \\
\hline 10 & q & 37 & 不 & 110 & $(\stackrel{3}{-})$ & 120 & $\left(\begin{array}{c}10 \\
(+)\end{array} \mid\right.$ & 30 & $\left(\begin{array}{c}0 \\
(-)\end{array}\right)$ & 2 & 0 & 0.95 & - & - & - & - & - & 、 \\
\hline 平 & & & & & 15.7 & & 20.0 & 19.0 & 2.2 & 7.3 & 6.5 & 0.53 & & & & & & \\
\hline
\end{tabular}

な差違は認められなかつた。

以上在總括すると, 被驗者の體溫任健常者に 比し季節的變動が大で, 外界氣溫（室溫）の影 響汇よる變動在來し易く，その本態は不明で西 るが,ワクチンによる發熱狀態も健常者に比し, 著明な差違を示し, 體溫調節機能の異常の存在 することが考へられる。
（5）覺醒アミンに對する反應 15藏一51 歲の 16 例の被驗者（今 3 例，우13例)，例及び 對照例として 17歲一35歲の健常者 10 例（今 3 例, 우 7 例) に, フェニールメチラミノブロパ ン（市販の Philopon) 注射液 2cc (6mg) の 靜脈內注射を行ひ，10 分間隔で 2 時間，1：主 として精神領域に於ける中樞姢經刺㦸效果 2. 
血㻺作用, 3. 脈搏, 呼吸, 體溫, 4. 發汗, 震顫, 心悸光進, 口喝, 其他の副作 用につき觀察し t。

その成績は第 6 表 (被驗例) 及び第 7 表 (對 照例) の通りである。血尉增加 (一) は $4 \mathrm{~mm}$

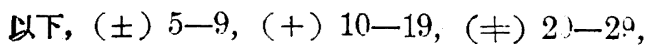

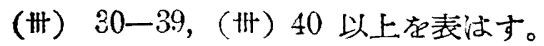

郎ち, 主として精种領域に現れた中樞神經刺 战效果は, 16 例の被驗例の中 7 例, 對照例で は 10 例の中 2 例が不變であつた。また對照例 では不變の 2 例の他の殆ど全例に明瞭な效果が 現れたが, 被驗例では不變のて例の他は, 殆ど 不督つもの 3 例, 少量服布時飞稀に見られると いふ Paradox な效果 (Bruns) と考へられる 淺眠を示したもの 1 例，健常者では殆ど見られ
ることがないといはれる，嗜眠，健忘を主徵侯 とする單純性意識混濁の現れたものが 2 例あつ た。

血壓上昇作用は, 被驗例及び對照例の兩群の 略 牛數が 10 分後に, 60 分後に心雨群の全 例が最大增加に達したが, 被驗例沙對照例に比 し, 最大增加值の小さいものが多く, 120 分後 飞は前者の 7 例はなほ $(+)$ 以上の增加を示し たが，後者では $( \pm)$ の 2 例以外の全例が $(-)$ であつた。郎ち, 被驗例は對照例飞比し, 一般 飞, 最大增加數が小で, 注射前血壓值飞復舊す る迄の時間が延長する傾问が認められるが，被 驗者の中には極端な增加（州）を示したものが 2 例西つた。

脈搏增加, 呼吸增加, 體溫上, 䒜注殆ど全例飞

第 8 表

\begin{tabular}{|c|c|c|c|c|c|c|c|c|c|c|}
\hline 症例 & 珄叧 & 伻齡 & 智能 & 程度 & $\begin{array}{l}\text { 糖投投 } \\
\text { 與前 }\end{array}$ & 30 分 & 60 分 & 90 分 & 120 分 & 最大算加 \\
\hline 1 & q & 26 & 族 & 㤎 & 85 & $+16(18.2)$ & $+15(17.6)$ & $+1 C^{\prime}(11.7)$ & $+10(11.7)$ & $16(18.2)$ \\
\hline 2 & 우 & 22 & & 葸 & 80 & $+32(40.0)$ & $+24(30.0)$ & $+6(7.5)$ & $-1(1.2)$ & $32(40.0)$ \\
\hline 3 & ㅇ & 44 & 疾i & 思 & 80 & $+11(13.7)$ & $+1(1.2)$ & $-2(2.5)$ & $-7(8.7)$ & $11(13.7)$ \\
\hline 4 & 우 & 33 & 放 & 墨 & 72 & $+16(22.2)$ & $+13(18.0)$ & $+8(11.1)$ & $+2(2.7)$ & $16(22.2)$ \\
\hline 5 & 우 & 51 & 椥 & 愚 & 90 & $+10(11.1)$ & $+21(23.3)$ & $+11(12.2)$ & $+1(1.1)$ & $21(23.3)$ \\
\hline 6 & 우 & 25 & 倡 & 銶 & 83 & $+3(3.6)$ & $+10(12.0)$ & $+5(6.0)$ & $+1(1.0)$ & $10(12.0)$ \\
\hline 7 & 우 & 35 & & 痴 & 67 & $+5(7.4)$ & $+2(2.9)$ & $-2(2.9)$ & $-7(10.4)$ & $5(7.4)$ \\
\hline 8 & q & 36 & 痴 & 思 & 92 & $+20(21.7)$ & $+13(14.1)$ & $+10(10.8)$ & $+8(8.6)$ & $20(21.7)$ \\
\hline 9 & ㅇ & 23 & 痴 & 䍐 & 90 & $+16(17.7)$ & $+9(10.0)$ & $+2(2.2)$ & $0(0)$ & $16(17.7)$ \\
\hline 10 & 우 & 33 & 族 & 葸 & 99 & $+5(5.0)$ & $+4(4.0)$ & $-7(7.0)$ & $-8(8.0)$ & $5(5.0)$ \\
\hline 11 & 우 & 22 & & 聅 & 101 & $+37(36.6)$ & $+22(21.7)$ & $+17(16.8)$ & $+4(3.9)$ & $37(36.6)$ \\
\hline 12 & ㅇ & 40 & 痴 & 䨿 & 79 & $+3(3.7)$ & $-4(4.9)$ & $-8(10.1)$ & $-9(11.3)$ & $3(3.7)$ \\
\hline 13 & $\delta$ & 42 & 痴 & 愚 & 95 & $+19(20.0)$ & $+2(2.1)$ & $0(0)$ & $-5(5.2)$ & $19(20.0)$ \\
\hline 14 & 우 & 18 & 痴 & 葸 & 95 & $+7(7.3)$. & $+1(1.0)$ & $-2(2.1)$ & $-5(5.2)$ & $7(7.3)$ \\
\hline 15 & $\delta$ & 15 & 族 & 愚 & 102 & $+6(5.8)$ & $-17(16.6)$ & $-20(19.6)$ & $-21(20.5)$ & $6(5.8)$ \\
\hline $1 i$ & 우 & 22 & & 愚 & 77 & $+27(35.0)$ & $+11(14.2)$ & $+3(3.8)$ & $+1(1.2)$ & $27(35.0)$ \\
\hline 17 & $\delta$ & 29 & 凬 & 鉣 & 74 & $+13(17.5)$ & $+15(20.2)$ & $+13(17.5)$ & $+11(14.8)$ & $15(20.2)$ \\
\hline 平均 & ノ & I & & & 85.9 & $+14.4(16.8)$ & $+8.3(10.0)$ & $+2.5(3.2)$ & $-1.4(1.5)$ & $15.5(18.2)$ \\
\hline
\end{tabular}

現れたが，兩群に於て著明な差違は認められな かつた。

其他の副作用として, 心悸穴進, 溫感, 口喝 頭痛が兩群に現れ, 惡心, 嘔吐, 尿意, 睡眠障 碍, 四䁌冷感; 震顕が對照例のみに, 發汗が被 例のみに現れた。 以上の結果から，被驗者の學醒フミン對する
反應は，對照例に比較して，一般に微弱である と言ひ得るが被驗者の中には, 對照例には見ら れぬ如き異常な反應を呈したものも少數認めら れた。

（6）食餌性血糖反應實驗材料泣， 15 歲一51 歲の 17 例 (今 3 例, 우14 例) 在用ひ t。 
$-32-(604)$

先つ最終の食事の約 12 時間後て於ける血糖 量を Hagedorn-Jensen 法飞より測定し, 次に $50 \mathrm{~g}$ の㑘萄糖を $150 \mathrm{cc}$ 溫湯に溶解して與〜, 其後 30 分每江 120 分の間の血糖量を測定し, 宾腹時血糖量江對する增加, 減少の程度を檢查 した。その成績住第 8 表の通りで西る。括弧內 の數值は增加, 減少の\%走す。

第 8 表に上れば，空腹時（葡萄糖投與前）血 糖量㳉 $102-67 \mathrm{mg} / \mathrm{dl}$ ，平均住 $85.9 \mathrm{mg} / \mathrm{dl}$ で ある。血糖の最大值に達した時刻は, 30 分が 14 例, $60^{\circ}$ 分が 3 例であつた。 Lajta が 8-16 歲の, 19 例の遲鈍性精神薄弱及び 22 例の興 奪性精神薄弱を脚ひて食餌性血糖反應飞關する 實驗を行つた結果によると(本實驗は彼の方法 飞做つて實施した), 空腹時血糖量は, 䢰 鈍性 $75-130 \mathrm{mg} / \mathrm{dl}$, 興舊性 $66-138 \mathrm{mg} / \mathrm{dl}$, , 平均 は兩群共 $102 \mathrm{mg} / \mathrm{dl}$ であつた。また增加の時 間的經過仗, 41 例の中 24 例が 30 分, 15例が 60 分, 2 例が120分で最大值に達した。この成績 被驗者の成績に比較すると, 個々の數值には 多少の異同が西るが, 全體としては大差を認め 得ない。

次江血糖の最大增加值江 $37-3 \mathrm{mg} / \mathrm{dl}$, 平均 $15.5 \mathrm{mg} / \mathrm{dl}$, その\%は $40.0-3.7 \%$, 平均 18.2 \%であつた。前述の Lajta の成績によれば, 最大增加の\%の平均は遲鈍性 $31 \%$, 興奮性 67 $\%$ ，この中特汇强い增加を示した興奮性の 12 例の本均は $85 \%$ であつた。郎ち, 被驗者の成 績は Lajta の遲鈍性の平均より約 $12 \%$ 低い值 を示してるる。この差は，恐らく，種々の貫驗 條件の相違に由來するものと考へられるが，こ の差異は彼の遲鈍性及び興䍜性の兩群の差36\%

(或は $54 \%$ ) より必遥か僅少であつて, こ れを度外視寸れば, 遲鈍性のものが興奮性のも の上り著明に低い值を示寸點に關しては, 我々 の被驗者は全例が彼の興奮性の平均より低く， 彼の成績に一致した結果が得られた。

最後に，室腹時血糖值飞對する增加の\%を各 時刻每にグラフに表示するところの所謂相對的 血糖曲線を作つてみると, 興䍜性の精神薄弱で は高い, 强い曲線型が, 遲鈍性のものでは平坦
な, 弱い曲線型が得られることが特銜的である と, Lajta は述べてるるが, 我ヶの被驗者の殆 ど全てが，遲鈍性に特徵的で西るといはれる本 坦な, 弱い曲線を示した。

（7）結 語 Lajta 让逮鈘性精神薄弱 の平坦な, 弱い血糖曲線はその全人格の無力性 (Asthenie) の部分現象であると述へ， Szondi は前述の 2 種類の對極的な曲線型によつて, Apathisch-Torpid な精神反應形式と InitativEretisch な反應形式在區別することが出來る といひ, Szondi 及び Laxは, 不關(Apathle) 緊張低下 (Hypotonie), 脫力 (Adynamie) 主症狀とし,「無力性 (Asthenisch) 症狀群」 の特徵を著明に示与ところの神經衰弱者が平坦 な相對的血糖曲線を表依すといふ事實から，平 坦な曲線は無力性症狀群の症候學的隨件現象で あると述べてるる。

Asthenie の定義汇關しては，1. 細長で力弱 く, 骨骼, 筋肉が無力で冈臟下垂症があり, 循 環采が弱く, 消化不良, 神經衰弱の特徴在もち Kretschmer の細長型の極端型, 或は Vegetative Nervosität (Westphal), Vegetative Stigmałisierung (Bergmann) と關聯在有す ると考八られるもの (Stiller) 2. 組織反應の 現れ方が弱く無力で西つて, 過敏體質の反對, 師ち組織反應微弱體質 (Standenath, Borcha$r t$ ）或は「種々の素質の队の或一群がとりまと まつて，より弱く現れ易いやうな身體傾问」を 有する崌鈍體質 (無力體質) (木田) の2 種觉 區別することが出來る。

前述の Szondi 及び Lax の 神經衰弱者の無 力性は 1. の度義江於ける無力性であることは 明らかであるが, Lajta の述べる遲銛性精神薄 弱の全人格の無力性も之に屬するとは考へられ ない。我々の實驗成績によれば，被驗者の中て は, 諸種の身體的, 生物學的反應が, 種々の程 度で微弱な個體が多く見られたといふ結果から 遲鈍性精神薄弱の無力性江，2.の定義仗於ける 無力性に相應すると考へるのが穻當である。即 ち, 結論として, 逮鈍性精神薄弱には遅鈍體質 （無力體質）（木田）飞屬する個體が多いとい 
ひ得る。

從つて, また, 本研究の結果は, 遌鈍性精神 薄弱之迤鈍體質（無力體質）との關聯，逑鈍體 質飞於ける身體的，生物學的反應態度といふ問 題に對して，一つの寄與をなすものであると考 几る。

\section{i 主要文献}

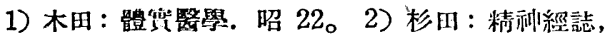
47 秋, 11 號。3) 榴井: 同前。 4) 滿川：慶大种經 科 15 周年記念論交莱, 昭 12 。 5 ) 吳, 沖中: 自律 种經系, 昭 19。6) 沖中: 自律种經機能ひ檢查法, 昭 22 。 7 ) 沖中: 自律种經系之臨床, 昭 23 。 8 ) 三 好, 稻田: 神經誌, 38 兊 3 號, 昭 9。9) 宮川外: 熊本䣽會誌, 13 兊 2 號, 炤 12 。 10 ) 金井, 杉田:

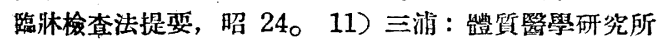

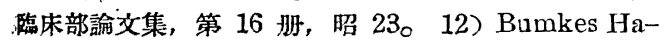
udb. d. Geisteskrankheiten, Bd, 10, 1928. 13) Eppinger, H. u. Hess, L. : Z. f. klin. Med., 67, 1931. 14) Hahn, H. u. Taeger, H. : Z.t. d. exp. Med., 76, 1931. 15) 木田：體質と种經質，炤 22 。

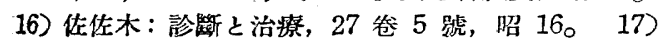
宮揢: 兒科誌, 47 兊 3 號, 昭 16 。 18 ) 長谷川外： 日本露事新報, $7 \mathrm{z} 2$ 號, 昭 12 。 19 ）坟野外: 兒科誌 44 兊 8 號, 昭 13。20) 北: 日本學校衛生, 25 兊

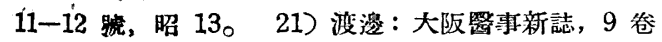
6 號, 昭 13 。 22 ) 庋津: 兒科誌, 47 参 12 號一 49 尖 9 號, 昭 16-18。 23 ) 柳澤外: 千葉醫會誌, 19 兊 10 號, 昭 16。24) 稻田: 醫海展望, 203-210 號, 昭 10 。25) 小泉: 體漫生理學, 炤 10 。 26C 近喰: 精神經誌, 46 参 9 號, 昭 17。27) Ebstein, W. u. Schwalbe, J. : Handb. d. prakt. Mdd., 1905.

28) Weygandt, W. : Jugendlichier Schwochsiun, 1936. 29) 有山: 精科經誌, 45 卷 12 號, 昭 16 。

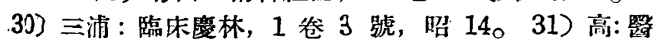

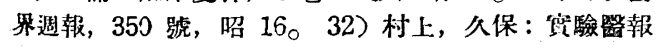

28 年 2 號, 昭 16。 33) 古潀, 藤生: 醫事公論, 1568 號, 炤 17 。34) 近藤, 柳下: 治療學雜誌, 12 卷 7 號, 炤 17 。35) 佐藤: 治潦及處方, 昭 18 。 36) 滕木: 臨林之研究, 23 参 1 號, 昭 21 。 37 )三 輪: 徏种經誌, 49 兊 1 號, 昭 21。38) 立津：精种經 誌, 51 兊 5 號, 昭 25。39) 野田外: 同前ó 40)井 上：同前。41) 竹山外：第 47 回精种种經會抄錄。 42) 疋田: 同前 43) 和田: 精种經誌, 50 参 2 號, 炤 23。 44) Nathanson, M. H. : Jour. A. M. A., 1937. 45) Davidotf, E. a. Reifenstein, E. C.: J. amer. med. Assoc., 108, 1937. 46) Bahnsen, P., Jacobsen, E. u. Thesleff, H.: Kl!̣n. Wschr., 193. 47) Hauschild, F. : Klin. Wschr., 20, 1941. 48) Bardley, C. : Amer. J. Psychiat., 94, 1937. 49) Molitsch, M. a. Eccbs, A.k. : Amer. J. Psychiat., 91, 1937. 50) Seifert, W. : Deut. med. Wschr., 1939. 51) Bruns, O. : Fortschritte d. Theraphe, 17, Jg., H. 3, 1941. 52) Püllen, C. : Münch. m ed. Wschr., 86, 1939. 53) Püllen, C. : Chirur., 11, 1939. 54) Franke, F.: Klin. Wschr., 17, 1938. 55) Szondi, L. : Bericht über d. 5. Kong. f. Heilpädag., 1. Teil Beiträg ezur Psychologie d, Pathologischen, 1930. 56) Lajta, i. : ibid. 57) Szoondi, L. u. Lax, H. : Z. f. d. gep. exp. med., 64, 1-2, 1929. 58) Wuth: Z. f. d. Neur. u. Psych.. 64, 1921. 59) Reiter, P. : Z. f. d. Leur., 107, 1927. 60) Pollak, L.: Klin. Wschr., 6, 41, 1927.

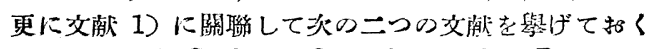
61) Hempel, C. G. u. Opoenheim, P. : Der Typnsbegritf im Lichte der neuen Logik, Wissenschaftstheoretische Unteruchungen zur Lonstitutionsforschung uud Psychologie, 1936. 62) 木田, 平井, 雨宮: 民族鬹生, 13 兊 1 號, 炤 21 。

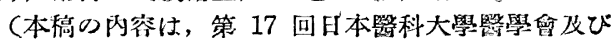
日本心理學會第 14 回大會に於て報告した。) 